\title{
Technical Note: Comparison of storage strategies of sea surface microlayer samples
}

\author{
K. Schneider-Zapp ${ }^{1}$, M. E. Salter ${ }^{2}$, P. J. Mann ${ }^{3}$, and R. C. Upstill-Goddard ${ }^{1}$ \\ ${ }^{1}$ Ocean Research Group, School of Marine Science and Technology, Newcastle University, Newcastle upon Tyne, \\ NE1 7RU, UK \\ ${ }^{2}$ Department of Applied Environmental Science (ITM), Stockholm University, Svante Arrhenius väg 8 , \\ 11418 Stockholm, Sweden \\ ${ }^{3}$ Woods Hole Research Center, 149 Woods Hole Road, Falmouth, MA, USA \\ Correspondence to: K. Schneider-Zapp (klaus.schneider-zapp@newcastle.ac.uk)
}

Received: 1 February 2013 - Published in Biogeosciences Discuss.: 18 February 2013

Revised: 29 May 2013 - Accepted: 2 June 2013 - Published: 22 July 2013

\begin{abstract}
The sea surface microlayer (SML) is an important biogeochemical system whose physico-chemical analysis often necessitates some degree of sample storage. However, many SML components degrade with time so the development of optimal storage protocols is paramount. We here briefly review some commonly used treatment and storage protocols. Using freshwater and saline SML samples from a river estuary, we investigated temporal changes in surfactant activity (SA) and the absorbance and fluorescence of chromophoric dissolved organic matter (CDOM) over four weeks, following selected sample treatment and storage protocols. Some variability in the effectiveness of individual protocols most likely reflects sample provenance. None of the various protocols examined performed any better than dark storage at $4{ }^{\circ} \mathrm{C}$ without pre-treatment. We therefore recommend storing samples refrigerated in the dark.
\end{abstract}

\section{Introduction}

The sea surface microlayer (SML) is only tens to hundreds of micrometers deep, but represents a physically, chemically and biologically distinct environment. It contains unique microbial communities, is a site for the synthesis and concentration of organic matter components, including transparent exopolymer particles (TEP) implicated in marine snow formation, and surface active substances (SAS) that cause damping of surface turbulence and subsequent suppression of air-sea gas exchange (Ćosović, 2005; Upstill-Goddard et al., 2003;
Cunliffe et al., 2011; Wurl et al., 2011; Salter et al., 2011). SAS in seawater are predominantly natural phytoplankton exudates, such as polysaccharides, proteins and lipids, and their degradation products (Gašparović, 2012), with additional contributions in coastal waters from terrestrial humic and fulvic acids. Production of SAS is thus seasonal and leads to strong seasonality of SML properties and air-sea gas exchange (Wurl et al., 2011).

Several methods for sampling the SML are in common use (Zuev et al., 2001; Cunliffe et al., 2013), most commonly the mesh screen (Garrett, 1965) and glass plates (Harvey and Burzell, 1972). Different sampling methods select different sampling depths (Cunliffe et al., 2013) and also have slightly different sensitivities for certain components (Zuev et al., 2001), which complicates study inter-comparison. Additionally, the complex physico-chemical nature of the SML and the strong seasonality and reactivity of some of its main components also present challenges to sample handling and storage. Routine analyses providing valuable SML characterisation include chromophoric dissolved organic matter (CDOM) absorbance (Helms et al., 2008; Frew et al., 2002) and fluorescence (Hudson et al., 2007). Total surfactant activity (SA) (Ćosović and Vojvodić, 1982) is also an important parameter due to the role of surfactants in air-sea gas exchange (Frew et al., 2002) but few data are available. For all of these methods, analysis in the field is usually not possible. Delays between sampling and analysis are thus inevitable and in the case of open ocean research cruises, these can extend over several weeks. Even where instrumentation is 
readily available the measurements can be time-consuming, making storage a significant issue for at least some samples. As some degree of SML sample storage is unavoidable, the development of storage protocols that minimise temporal degradation and contamination are essential.

There is currently little consensus regarding appropriate maximum storage times or recommended sample treatments for the routine SML analyses outlined above. Although earlier studies addressed sample storage for individual sea water components, reported results are sometimes conflicting and as far as we are aware the simultaneous evaluation of several storage protocols for several sea water analytes has not been adequately undertaken, and this is certainly so for the SML. To address this deficiency we examined the effects of several established storage protocols on the analysis of SA and CDOM absorbance and fluorescence in SML samples.

\section{Review of storage methods}

To set the context for our study it is appropriate here to briefly review some commonly used methods for preserving organic matter (OM) samples collected in natural waters.

Refrigeration in the dark at typically $4{ }^{\circ} \mathrm{C}$ is in common use for CDOM samples (Coble et al., 1998; Baker, 2002; Stedmon et al., 2003; Wickland et al., 2007; Fellman et al., 2009; Hood et al., 2009; Lapworth et al., 2009). However, while one study found no change in CDOM absorption in samples refrigerated for less than $24 \mathrm{~h}$ (Mitchell et al., 2000), another reported fluorophore-specific declines in fluorescence intensity dependant upon sample provenance (Hudson et al., 2009). Hunter and Liss (1981) found small SA losses from samples dark-stored at $6^{\circ} \mathrm{C}$ for up to a week, but an increase of $20 \%$ after 34 days. Freezing of filtered samples at $-20{ }^{\circ} \mathrm{C}$ is also widely used for CDOM storage (Coble et al., 1998; Murphy et al., 2008; Conmy et al., 2009; Walker et al., 2009; Gao et al., 2010; Spencer et al., 2010; Yamashita et al., 2010b) but again sample provenance appears to be important; highly coloured samples comprising mostly allochthonous OM tend to show greater changes during freeze/thaw than more optically clear autochthonousdominated OM samples. Two studies of a range of freshwaters found that after freeze/thaw, fluorescence intensities and adsorption coefficients showed both increases and decreases (Spencer et al., 2007a; Hudson et al., 2009), although overall CDOM loss was observed and protein-, humic-, and fulvic-like fluorophore intensities all declined (Hudson et al., 2009). Both studies concluded that there were no simple relationships between initial sample characteristics and changes during freeze/thaw and that correcting their data for this effect was therefore not possible. On the other hand, Yamashita et al. (2010b) found CDOM absorbance to be unaffected by freezing, although FDOM data were compromised, and Gao et al. (2010) found that changes after freezing were less than $15 \%$. Other studies also found minimal effects of freeze/thaw on OM optical properties (Conmy et al., 2009; Yamashita et al., 2010a), and Spencer et al. (2010) found that after freeze/thaw, changes in absorbance, spectral slope, specific UV absorbance, and fluorescence were within analytical error and always less than $\pm 2 \%$.

Sample storage after chemical poisoning to arrest biological activity is another approach that has been commonly used in the literature, of which five types are common: (i) acidification to $\mathrm{pH} \sim 2-3$ using $\mathrm{HCl}$ or $\mathrm{H}_{3} \mathrm{PO}_{4}$; (ii) chloroform $\left(\mathrm{CHCl}_{3}\right)$; (iii) sodium azide $\left(\mathrm{NaN}_{3}\right)$; (iv) mercuric chloride $\left(\mathrm{HgCl}_{2}\right)$ (Kaplan, 1992; Kirkwood, 1992; Benner and Hedges, 1993; Ferrari et al., 1996; Wiebinga and de Baar, 1998; Kattner, 1999; Gardolinski et al., 2001; Aufdenkampe et al., 2007; Hur et al., 2007; Bouillon et al., 2009; Stubbins et al., 2010); and (v) Formalin (Wurl et al., 2009). A note of caution is the possible modification of the analytes of interest but only the effect of acidification has been examined extensively, as it is often used to prevent microbial degradation in CDOM samples and because lowering the $\mathrm{pH}$ reduces the tendency towards metal-DOM complexation. However, CDOM absorption has been observed to increase with increasing $\mathrm{pH}$ (Andersen et al., 2000) and acidification is also reported to change fluorescence intensities and to introduce spectral shifts. For example, Patel-Sorrentino et al. (2002) observed an increase in fluorescence intensity with increasing $\mathrm{pH}$ between 1 to $10-11$ and a decrease at $\mathrm{pH} 12$; Mobed et al. (1996) found a red shift in florescence intensity maxima with increasing $\mathrm{pH}$ in soil-derived humics. The same study also reported a blue shift with increasing $\mathrm{pH}$ in aquatic derived DOM. Spencer et al. (2007a) found that $\mathrm{pH}$ significantly affects CDOM and EEM measurements and that it is especially severe at extreme $\mathrm{pH}$ values. Based on this evidence the acidification of samples for CDOM absorbance and fluorescence measurements should be avoided.

While mercuric chloride is deliberately used to inhibit microbial growth in some studies, there are consequent effects on CDOM (Kratzer et al., 2000; Helms et al., 2008; Spencer et al., 2009) and it has been shown to quench DOM fluorescence (Fu et al., 2007; Yamashita and Jaffe, 2008). Sodium azide has been reported to have no effect (Ferrari et al., 1996; Astoreca et al., 2009) but also to cause up to $10 \%$ increase in absorption (Tiltstone et al., 2002). Patel-Sorrentino et al. (2002) found that sodium azide had no measurable effect on the EEMs of two humic-like fluorophores. The use of toxic chemicals is also problematic from a practical standpoint. Chloroform is difficult to handle because of its volatility and its potential loss through plastic bottles (Kremling and Brugmann, 1999), while mercuric chloride and sodium azide are very toxic to aquatic organisms and may have long term adverse environmental effects (hazardous waste).

Previous studies focussed on single aspects and sometimes reported storage results are conflicting. To the knowledge of the authors, a comparative test for the effects of different treatments on several measurements has not been conducted. 
Table 1. Treatments used for the SML samples. All samples were stored in the dark and, with the exception of treatment 7 , at $4{ }^{\circ} \mathrm{C}$.

\begin{tabular}{|c|c|c|}
\hline No. & Treatment & Sampling location \\
\hline 1 & No treatment & Estuarine \& riverine \\
\hline 2 & Fixed with $1 \%$ Formalin (final concentration) (Wurl et al., 2009) & Estuarine \\
\hline 3 & $\begin{array}{l}\text { Poisoned with } 6 \mu \mathrm{molL}^{-1} \mathrm{AgNO}_{3} \text { (Kim et al., 2008). The salt was } \\
\text { baked at } 200^{\circ} \mathrm{C} \text { to remove remnants of surfactants before making up } \\
\text { the poison }\end{array}$ & Estuarine \\
\hline 4 & Filtered with silver filter & Estuarine \& riverine \\
\hline 5 & $\begin{array}{l}\text { Filtered with } 0.2 \mu \mathrm{m} \text { surfactant free cellulose acetate (SFCA) filter (Ku- } \\
\text { jawinski et al., 2002) }\end{array}$ & Estuarine \& riverine \\
\hline 6 & $\begin{array}{l}\text { Filtered with } 0.2 \mu \mathrm{m} \text { surfactant free cellulose acetate (SFCA) filter and } \\
\text { poisoned with } \mathrm{HgCl}_{2}\end{array}$ & Estuarine \& riverine \\
\hline 7 & $\begin{array}{l}\text { Filtered with } 0.2 \mu \mathrm{m} \text { surfactant free cellulose acetate (SFCA) filter and } \\
\text { frozen at }-20^{\circ} \mathrm{C}\end{array}$ & Estuarine \& riverine \\
\hline
\end{tabular}

We tested the effects of different established storage protocols on SA, CDOM, and fluorescence.

\section{Materials and methods}

All sampling and laboratory equipment was acid-washed with $10 \% \mathrm{HCl}$ and rinsed three times with ultra-pure water (Milli-Q, Millipore System Inc., USA) prior to use. Glass equipment additionally was baked at $450^{\circ} \mathrm{C}$ overnight. SML samples were collected from the Tyne estuary (NE UK) on 17 March 2011 (salinities 0 and 17.4), 12 May 2011 (salinity 17.0) and 1 June 2011 (salinity 15.8) using a Garret screen (Garrett, 1965) (mesh 16, wire diameter $0.36 \mathrm{~mm}$, opening $1.25 \mathrm{~mm}$ ) into "aged" plastic bottles (i.e. all leachable components removed) and transported to the laboratory. A $5 \mathrm{~L}$ sample was collected at each station over a duration of approximately 2 hours. The Garrett screen was selected due to its ease of use even at high winds and its wide application in the literature. Although different sampling devices will result in slightly different samples due to differences in SML sample depth (Cunliffe et al., 2013), there is also great variability between sampling locations and times which will equally affect storage results. These natural variations are considered much higher than variations which are potentially introduced by the choice of the sampling method. Therefore we consider our results to be applicable for other sampling techniques as well.

In the laboratory, the samples were pumped using a peristaltic pump and silicone perstaltic tubing into $15 \mathrm{~mL}$ sterile polypropylene plastic tubes or $20 \mathrm{~mL}$ glass bottles for later analysis. For treatments which involved filtration, the respective filter was inline. To make sample handling as consistent as possible, unfiltered samples were pumped through empty filter holders. Subsequently, for treatments involving poisoning, the poison was applied using pipettes before storing at $4{ }^{\circ} \mathrm{C}$ or $-20^{\circ} \mathrm{C}$, depending on the treatment. All samples were collected in triplicate. For each treatment, 3 repli- cates $\times 4$ time points $\times 3$ variables $(\mathrm{SA}, \mathrm{CDOM}, \mathrm{FDOM})$, i.e. 36 , tubes/bottles were prepared (for treatments stored in both glass and plastic, 36 each).

The selected treatments are listed in Table 1 and are all in common use (see below). Filtering removes bacteria and thereby reduces bio-degradation but it also removes particulate matter and hence a significant portion of SAS. Consequently it has been recommended to measure SA on unfiltered samples (Ćosović, 2005). Poisoning samples by various means arrests bio-degradation but can lead to cell lysis and the leaching of SAS (Lee and Fisher, 1992; Gardner et al., 1983). Our selected procedures examined the net result of all of these. Poisoning by $\mathrm{AgNO}_{3}$ and $\mathrm{HgCl}_{2}$ were examined. Acidification processes were not considered due to the problems found in previous studies (Sect. 2).

For all protocols, the first sample $\left(t_{0}\right)$ was analysed as soon as possible after treatment (i.e. the same or following day). All samples were kept in the dark and all, except treatment 7 which was kept frozen at $-20^{\circ} \mathrm{C}$, were kept at $4{ }^{\circ} \mathrm{C}$ following common practice (Coble et al., 1998; Baker, 2002; Stedmon et al., 2003; Wickland et al., 2007; Fellman et al., 2009; Hood et al., 2009; Lapworth et al., 2009). Subsequent analyses were carried out after one, two, and four weeks. Treatments 1 and 6 were stored both in glass and polypropylene bottles to examine the comparative influences of these materials. All others, i.e. treatments $2-5$ and 7 , were stored in polypropylene only.

SA was measured by phase-sensitive AC voltammetry (Ćosović and Vojvodić, 1982) (Metrohm 797 VA Computrace, Metrohm, Switzerland) with a hanging mercury drop, a silver/silver chloride reference electrode and a platinum wire auxiliary electrode. Calibration used the non-ionic soluble surfactant Triton T-X-100. Samples were brought to salinity 35 prior to measurement by adding surfactant-free $3 \mathrm{molL}^{-1}$ $\mathrm{NaCl}$ solution. For each measurement, a new mercury drop was created and the first few drops discarded. Surfactants accumulated on the drop at $V=-0.6 \mathrm{~V}$ for $15 \mathrm{~s}$ with stirring 
Table 2. Characteristics of identified PARAFAC components. Maximal excitation and emission wavelengths are given, secondary excitation maxima are shown in parentheses. Description contains previously assigned characteristics and names of similar components as shown in the References column.

\begin{tabular}{lllll}
\hline Comp. & $\operatorname{Ex} \lambda(\mathrm{nm})$ & $\operatorname{Em} \lambda(\mathrm{nm})$ & Description & References \\
\hline 1 & 265 & 533 & Humic-like terrestrial DOM & Murphy et al. (2008) \\
2 & $<250(305)$ & 425 & Humic-like, low molecular weight & Murphy et al. (2008), Fellman et al. (2010) \\
3 & $<250(365)$ & 479 & Humic-like, high molecular weight & Fellman et al. (2010) \\
4 & 265 & 429 & Reduced, humic-like group & Cory and McKnight (2005) \\
5 & 280 & 342 & Tryptophan-like, amino acids free or bound & Murphy et al. (2008), Fellman et al. (2010) \\
\hline
\end{tabular}

SA

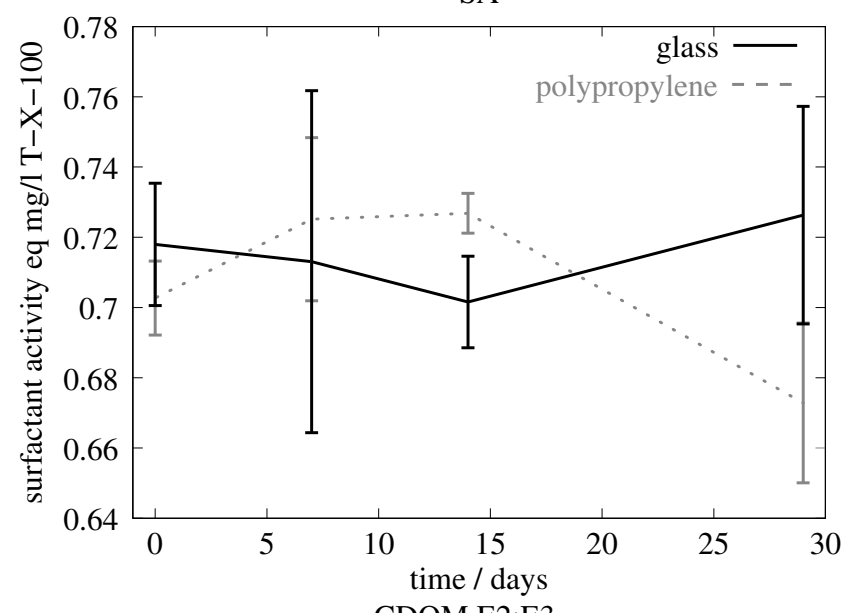

CDOM E2:E3

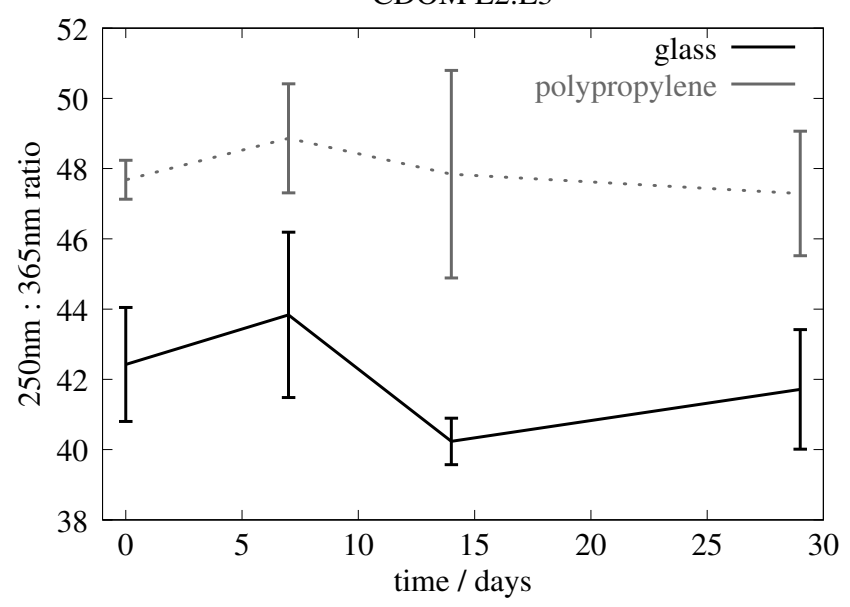

Fig. 1. Surfactant activity (SA) and CDOM $E_{2}: E_{3}$ vs. storage time for estuarine SML samples stores in glass and plastic, SA (top) exemplary for the situation without change, and CDOM $E_{2}: E_{3}$ (bottom) as the only example where there is an influence.

(1000 rpm). Alternating voltage scans of $10 \mathrm{mV}$ at $75 \mathrm{~Hz}$ produced a current which was measured. Each response was corrected for the added $\mathrm{NaCl}$ solution and expressed as an equivalent T-X-100 concentration.

CDOM absorbance and fluorescence (Spencer et al., 2007b) were determined by UV/VIS spectrophotometry
(Varian Cary 100 Bio) and UV/VIS spectrofluorometry (Varian Cary Eclipse Fluorescence Spectrophotometer), respectively (Varian Inc, USA). Both used $10 \mathrm{~mm}$ path length quartz cuvettes, rinsed three times with ultra-pure water and once with sample before each measurement. Ultra-pure water blanks were measured at the start and end of each run. Absorbance was measured over the wavelength range $800 \mathrm{~nm}-200 \mathrm{~nm}$ in $1 \mathrm{~nm}$ steps. Acquired spectra were corrected for drift by subtracting the mean $700 \mathrm{~nm}$ to $800 \mathrm{~nm}$ absorption (samples are transparent in that range) and the blank spectrum was subtracted. Spectral slopes $S$ (Helms et al., 2008) and the $250 \mathrm{~nm}$ to $365 \mathrm{~nm}$ absorption ratio (also called $E_{2}: E_{3}$ ) were used to indicate dissolved organic matter (DOM) composition (or "quality"). $E_{2}: E_{3}$ tracks changes in DOM molecular size and $S$ is an index of average DOM characteristics (chemistry, source, diagenesis). Both are largely independent of CDOM concentration (Helms et al., 2008). For estimating $S$ we used nonlinear regression on the wavelength region $350 \mathrm{~nm}$ to $400 \mathrm{~nm}$. CDOM fluorescence excitation-emission matrices (EEMs) were collected over excitation wavelengths $250 \mathrm{~nm}-450 \mathrm{~nm}$ in $5 \mathrm{~nm}$ steps and emission wavelengths $280 \mathrm{~nm}-600 \mathrm{~nm}$ in $4 \mathrm{~nm}$ steps. EEMs were averaged over $0.1 \mathrm{~s}$. Blank scans were subtracted from sample EEM matrices, which were then corrected for inner filter and instrument effects (Cory et al., 2010). $\mathrm{HgCl}_{2}$ quenches DOM fluorescence (Fu et al., 2007; Yamashita and Jaffe, 2008), hence we did not measure the fluorescence of $\mathrm{HgCl}_{2}$ poisoned samples. In total, 186 resulting EEMs were modelled with parallel factor analyses (PARAFAC; Stedmon and Bro, 2008). Five different fluorophores were identified using split-half validation and residual analyses (Table 2).

Statistical tests evaluated any significant differences. For examining glass vs. plastic, we fitted a linear model with generalised least squares and varying variances. An analysis of variance (ANOVA) was then used to determine whether the variable "tube material" exerts no influence (i.e. the factor was compatible with zero). Rejections were at the $5 \%$ level. For comparing compatibility with no change, each variable (SA, CDOM $S$, CDOM $E_{2}: E_{3}$ ) and each treatment were tested separately using an ANOVA. For investigating the effect of the treatments, each treatment was compared to "no treatment" using a linear model fitted with generalised 


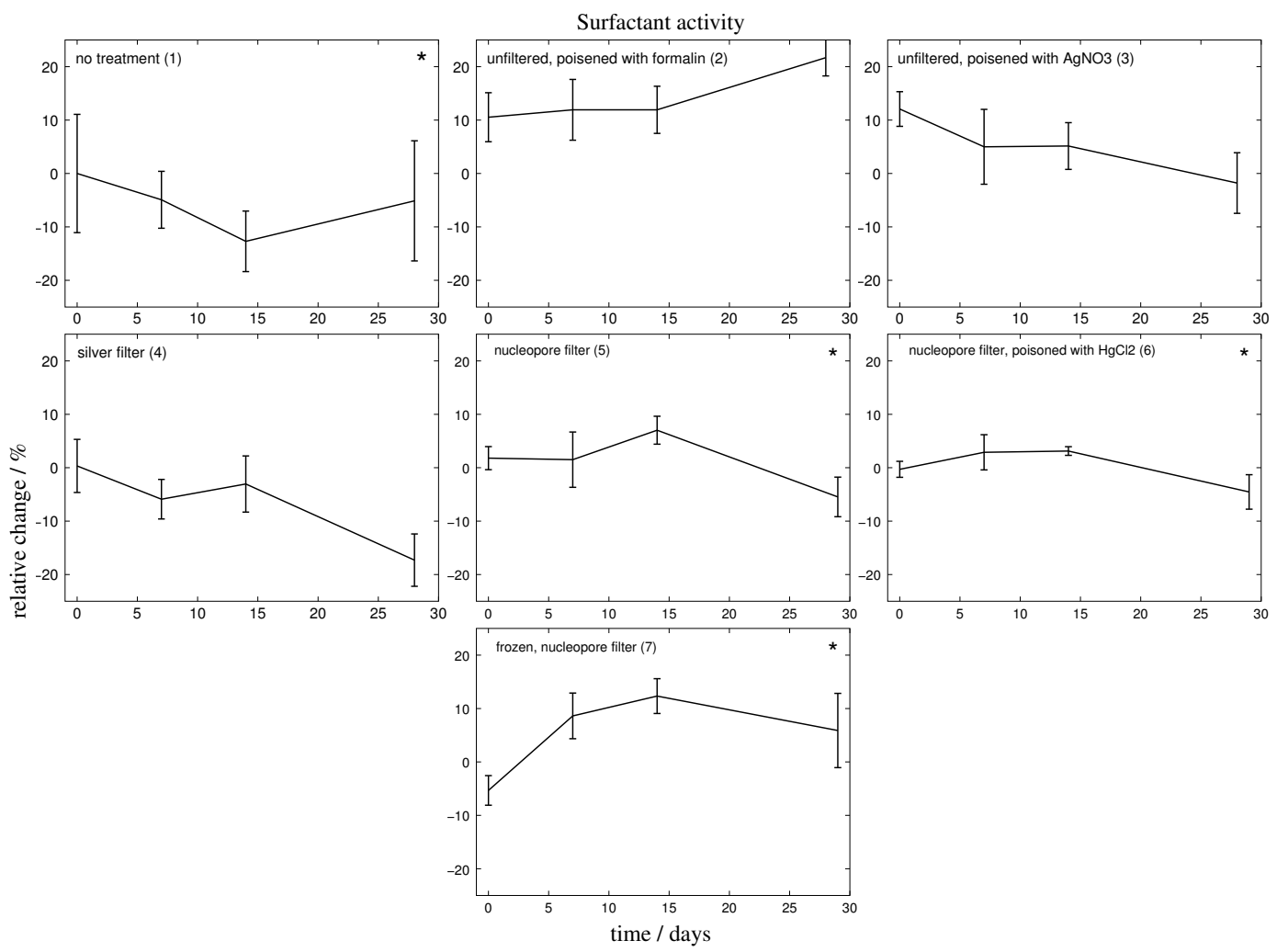

Fig. 2. Relative change of surfactant activity (SA) in respect to "No treatment" at $t_{0}$ vs. storage time for SML samples collected from the Tyne estuary for different treatments as detailed in Table 1 . Differences at $t_{0}$ are caused by treatment effects. Treatments are labelled in each figure and marked with a star if compatible with no change over time.

least squares. An ANOVA then tested if the parameter "treatment" had no influence. Statistics were calculated using the "R" software package. For every analysis, the statistics were checked using Q-Q plots and the distribution of residuals. Results which did not pass were discarded. Except for the statistical tests which operated on the original values, results were normalised to those for no treatment at $t_{0}$ to facilitate direct comparisons of changes during storage. Errors are expressed as the standard deviation of the triplicate analyses.

\section{Results and discussion}

We found that in all instances except CDOM $E_{2}: E_{3}$ for samples treated with $\mathrm{HgCl}_{2}$, storage in either glass or polypropylene did not significantly affect our analytical results (SA $p=0.45$, CDOM $S p=0.55, \mathrm{CDOM} E_{2}: E_{3}$ for silver filter $p=0.74)$. Figure 1 shows the comparison graphically, for SA as example for the cases with no influence, and for CDOM $E_{2}: E_{3}$ as the only case where there is an influence.

The selected treatments produced varying SA responses (Fig. 2). Formalin (treatment 2) produced an initial increase of $10 \%$ at $t_{0}$, which may reflect additional DOM leached from dying cells. If so, it is evidently essentially complete immediately following the addition. The filtered frozen sample (treatment 7) initially showed lower SA, likely due to particulate matter removal, whereas the unfrozen filtered sample (treatment 5) did not. This could be explained by clogging, causing a change in the effective filter pore size. Poisoning apparently partly compensated surfactant removal by filtering by introducing leached material (treatments 4 and 6 ). The untreated sample showed a maximal change of $-10 \%$. Only the untreated sample $(p=0.52)$, frozen $(p=0.17)$ and poisoning with $\mathrm{HgCl}_{2}(p=0.06)$ are compatible with no change over time.

CDOM responses are shown in Figs. 3 and 4. Formalin introduced significant absorption even in blank water samples, which precludes its use in CDOM storage protocols. $\mathrm{HgCl}_{2}$ significantly changed the absorption at small wavelengths: the $250 \mathrm{~nm}$ to $365 \mathrm{~nm}$ absorption ratio changed 10-fold (off scale in Fig. 4). Silver filtration and freezing also led to large changes. $\mathrm{AgNO}_{3}$ gave the best performance with changes up to $15 \%$ in $E_{2}: E_{3}$ and $20 \%$ in $S$, with the untreated sample showing changes up to $20 \%$. 

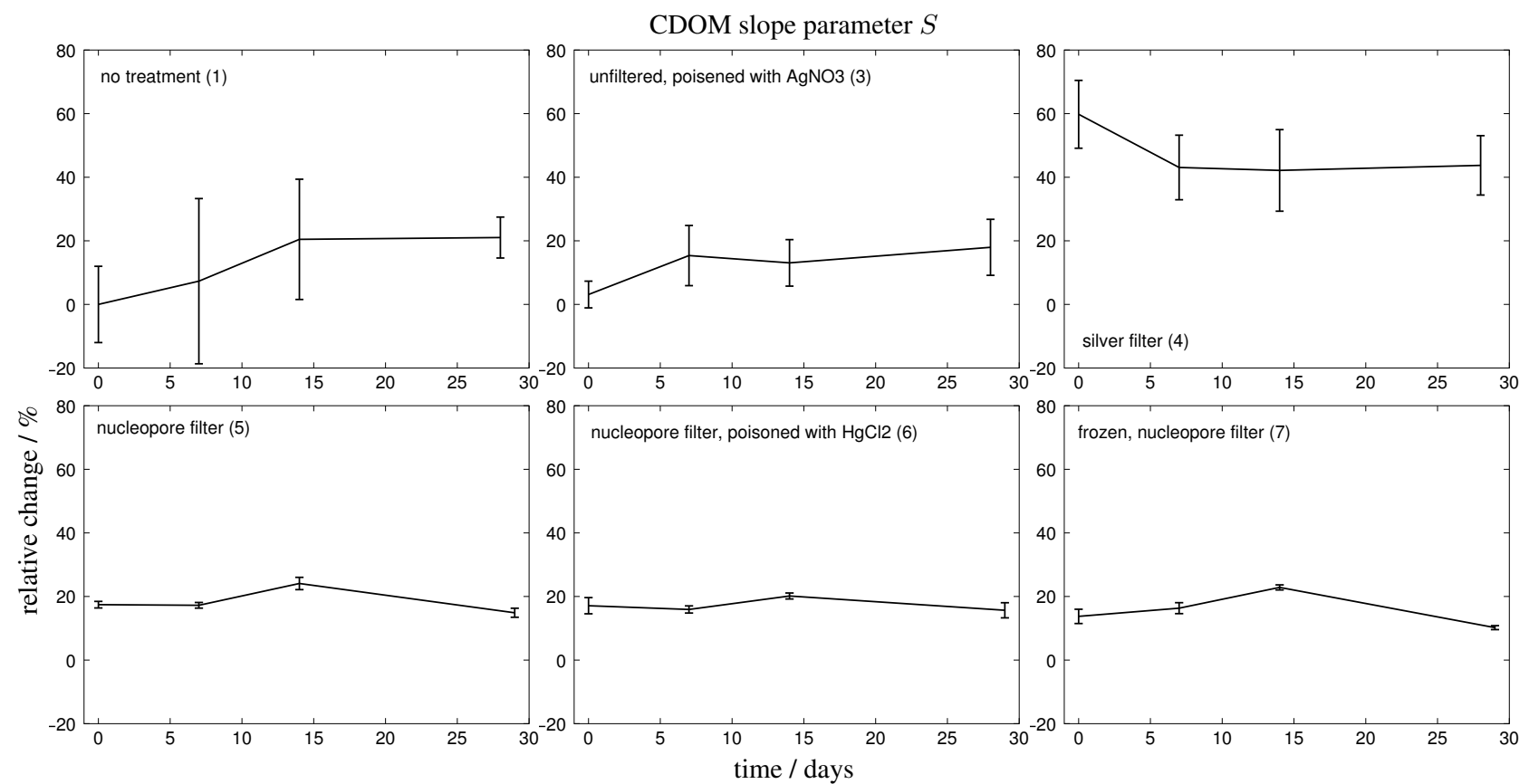

Fig. 3. Relative change of CDOM slope parameter $S$ in respect to "No treatment" at $t_{0}$ vs. storage time for SML samples collected from the Tyne estuary for different treatments as detailed in Table 1 . Differences at $t_{0}$ are caused by treatment effects. Treatments are labelled in each figure.
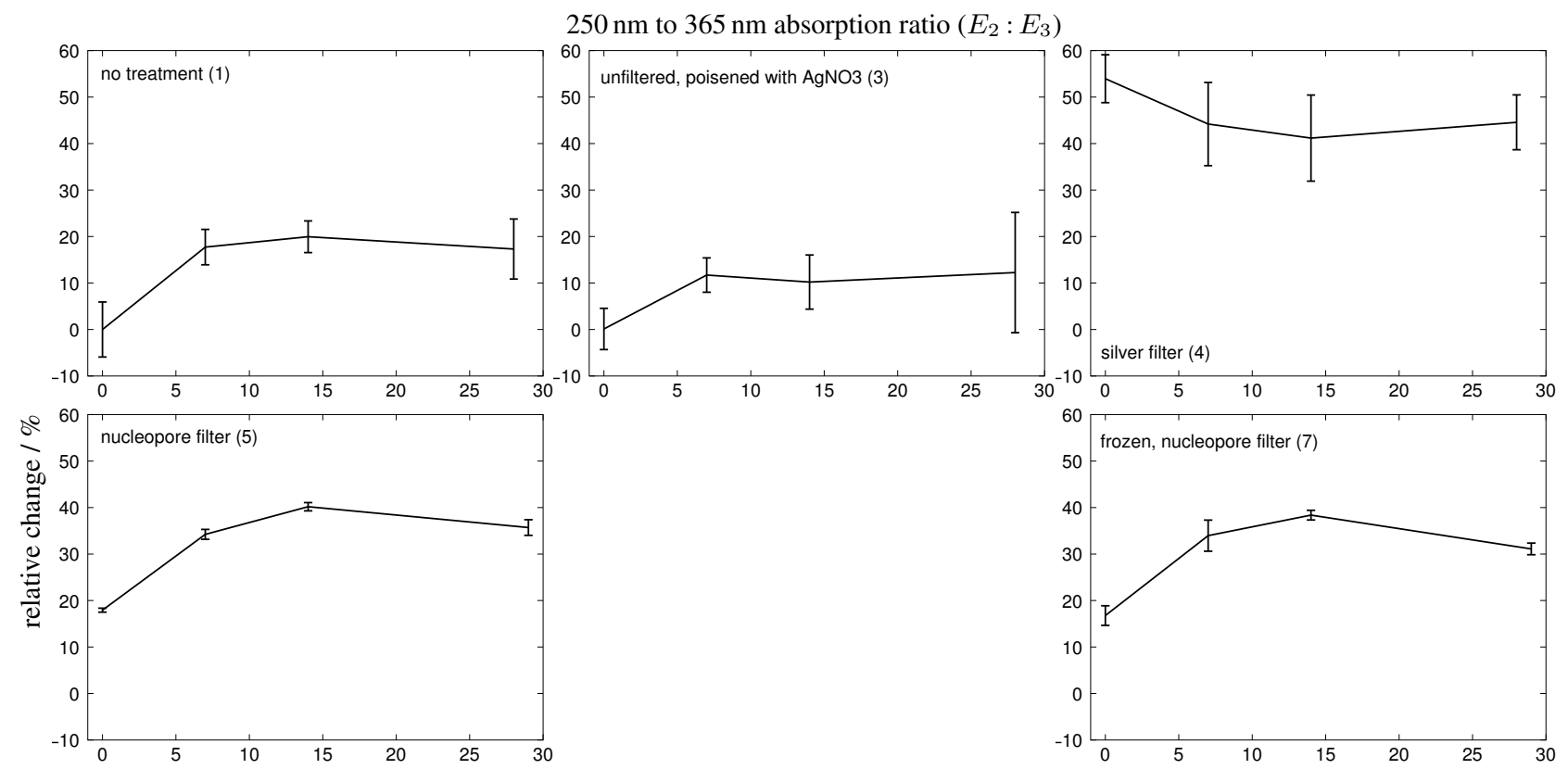

time / days

Fig. 4. Relative change of $250 \mathrm{~nm}$ to $365 \mathrm{~nm}$ absorption ratio $\left(E_{2}: E_{3}\right)$ in respect to no treatments at $t_{0}$ vs. storage time for SML samples collected from the Tyne estuary for different treatments as detailed in Table 1. Differences at $t_{0}$ are caused by treatment effects. Treatments are labelled in each figure. Note that $\mathrm{HgCl}_{2}$ is off scale and thus not shown. 
Surfactant activity
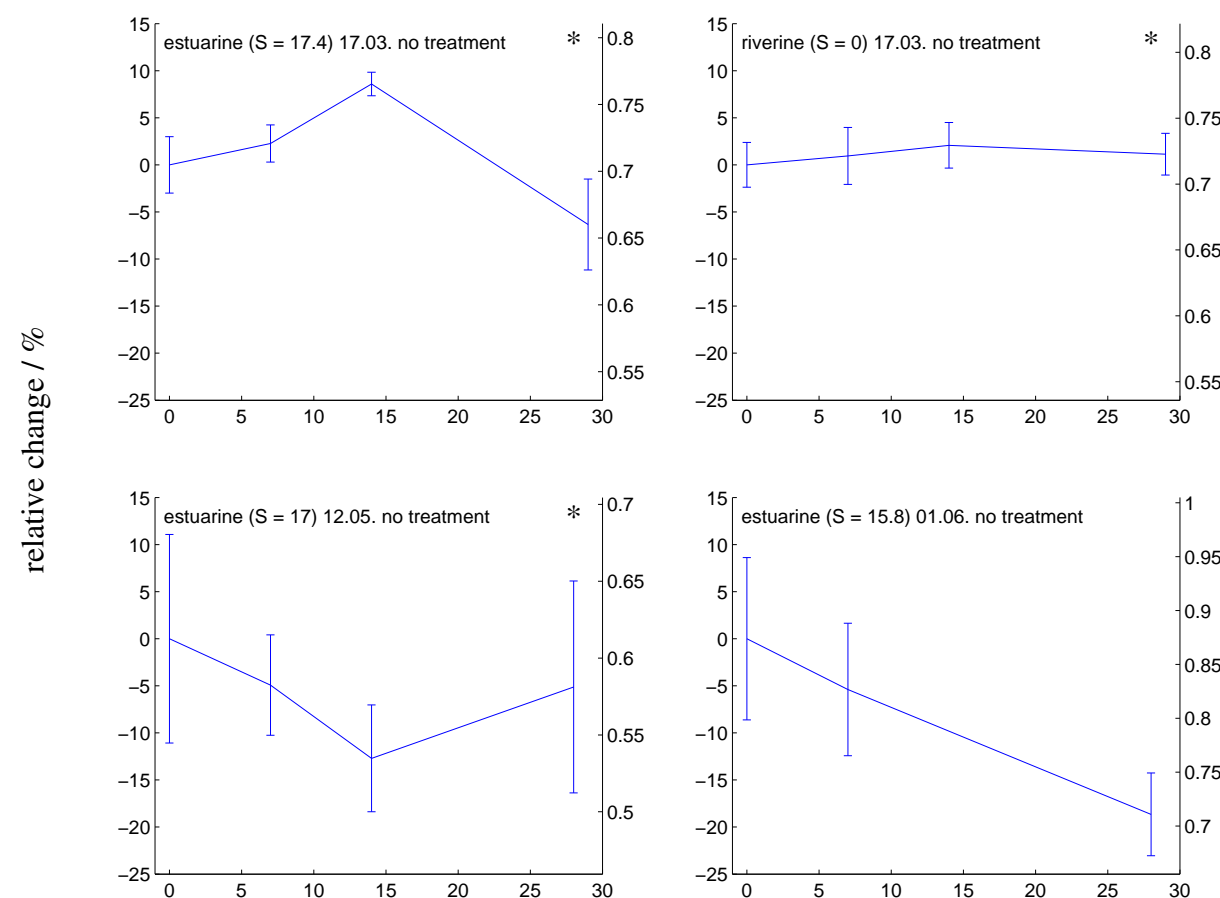

time / days

Fig. 5. SA vs. storage time for untreated SML samples collected from the Tyne estuary at two different locations (estuarine and riverine, sampling days and salinities $S$ are stated in the plots) and on different days. Note that the left axis shows relative change, while the right axis shows absolute values. Data compatible with no change over time is marked with a star.

Table 3. Statistical evaluation of no effect of storage time ( $p$ value). Tests were run separately for each treatment (as detailed in Table 1) and variable. For $p<0.05$ time is considered to have a significant influence. Unmeasured data are shown as n/a; statistics that did not pass the quality control as "-_".

\begin{tabular}{lrrr}
\hline Treatment & SA & CDOM $S$ & CDOM $E_{2}: E_{3}$ \\
\hline 1 & 0.52 & 0.12 & 0.05 \\
2 & 0.004 & $\mathrm{n} / \mathrm{a}$ & $\mathrm{n} / \mathrm{a}$ \\
3 & 0.004 & - & 0.14 \\
4 & 0.002 & 0.14 & 0.21 \\
5 & 0.10 & - & - \\
6 & 0.06 & 0.70 & 0.58 \\
7 & 0.17 & 0.36 & 0.10 \\
\hline
\end{tabular}

Table 3 shows the results of the statistical test against no change over time (disregarding initial change compared to the untreated sample) for all variables and treatments. Overall, none of the sample storage protocols examined performed any better than "no treatment". Table 4 shows the results for the statistical test against "no treatment". Nearly all treatments are significantly different (for SA only silver
Table 4. Statistical evaluation of no effect of treatment ( $p$ value) Each treatment as detailed in Table 1 was separately tested against "No treatment". For $p<0.05$ the treatment is considered to be significantly different from "No treatment".

\begin{tabular}{lrrr}
\hline Treatment & SA & CDOM $S$ & CDOM $E_{2}: E_{3}$ \\
\hline 2 & 0.002 & 0.97 & 0.12 \\
3 & 0.000 & $\mathrm{n} / \mathrm{a}$ & $\mathrm{n} / \mathrm{a}$ \\
4 & 0.80 & 0.000 & - \\
5 & 0.000 & - & 0.000 \\
6 & 0.000 & - & - \\
7 & - & 0.000 & 0.000 \\
\hline
\end{tabular}

filter (4), and for CDOM only Formalin (2) are not significantly different). For no treatment all investigated variables are compatible, thus all pre-treatments significantly modify the samples.

Perhaps unsurprisingly, changes during storage depend on the initial SAS concentration and composition. Figure 5 shows SA vs. time for the four samples examined: high SA freshwater and three lower SA estuarine waters. Only the estuarine sample from 01/06 showed any clear downward trend 


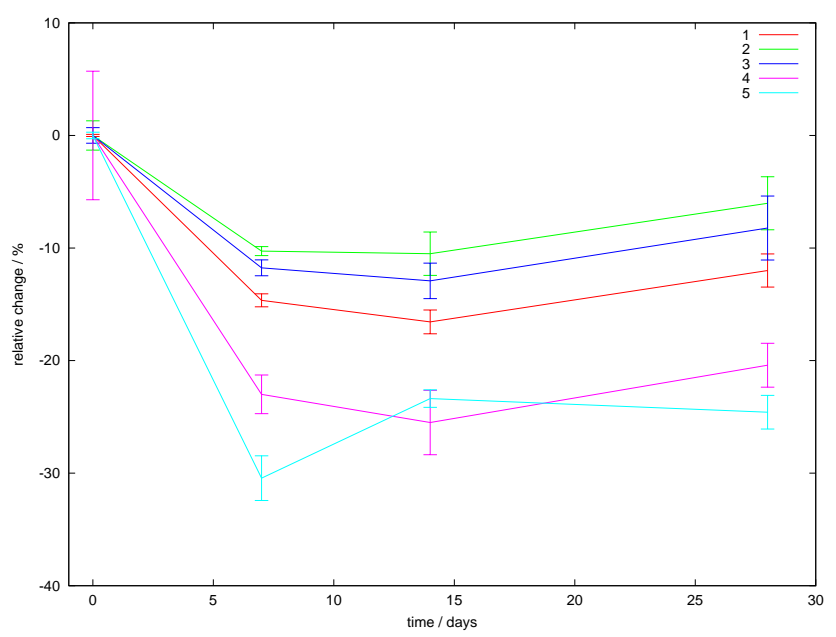

Fig. 6. Relative change of the five different fluorescence components as detailed in Table 2 vs. storage time for the untreated sample.

in SA; none of the others showed any significant temporal change ( $p=0.12, p=0.63$, and $p=0.53$, respectively). Initial changes due to the treatments (e.g. SAS leaching due to poisoning) also showed significant scatter for the different sampling locations and times, indicating that treatment effects cannot be easily predicted (data not shown).

Different SAS components degrade differently. Figure 6 shows relative changes in fluorescence components in the untreated sample. Tryptophan-like substances (component 5) and reduced humic-like groups (component 4) apparently degrade more rapidly than humic-like substances (components 1-3).

Findings of previous studies for CDOM and FDOM (Sect. 2) support the notion that changes in sample characteristics during storage can vary greatly, dependent not only on the selected sample treatment and storage time, but also on the initial sample composition. Our comparison of SA and CDOM changes of the same samples shows that SA and CDOM do not always behave similarly. Consequences for the subsequent analysis of SML samples stored according to various protocols may therefore be difficult to predict precisely with any great confidence. However within error changes over time for untreated samples during the first 14 days of storage are not significant for most samples.

\section{Conclusions}

A storage experiment using SML samples of varying salinities and seven different storage protocols showed that measured surfactant activity and CDOM absorption and fluorescence all depended on sample provenance as well as initial sample treatment and subsequent storage times. Moreover, all analyses showed significant scatter between triplicates and none of the several protocols examined performed any better than that of "no treatment". This highlights the difficulty of devising adequate storage protocols for SML samples. If all variables are considered, none of the tested protocols were compatible with "no treatment". This is probably due to the potential problem of organic material leaching from dying cells on poisoning and the likely removal of significant particulate organic matter on filtration. Therefore we must conclude that where the storage of samples for SAS and CDOM analysis is necessitated by circumstances, such samples should remain untreated and be stored at $4{ }^{\circ} \mathrm{C}$ in the dark for as short a time as possible. For storage of 7 days we found this protocol to result in an error of less than $12 \%$ in SA compared to samples analysed immediately following collection and for most samples, temporal changes are not significant within the first 14 days of storage.

Acknowledgements. We acknowledge and appreciate funding made available by the German Research Foundation (DFG; research fellowship to K. Schneider-Zapp), the UK Natural Environment Research Council (NERC; Grant number NE/IO15299/1), and the School of Marine Science and Technology, Newcastle University.

Edited by: G. Herndl

\section{References}

Andersen, D., Alberts, J., and Takacs, M.: Nature of natural organic matter (NOM) in acidified and limed surface waters, Water Res., 34, 266-278, 2000.

Astoreca, R., Rousseau, V., and Lancelot, C.: Coloured dissolved organic matter (CDOM) in Southern North Sea waters: Optical characterization and possible origin, Estuarine, Coast. Shelf Sci., 85, 633-640, 2009.

Aufdenkampe, A., Mayorga, E., Hedges, J., Llerena, C., Quay, P., Gudeman, J., Krusche, A., and Richey, J.: Organic matter in the Peruvian headwaters of the Amazon: Compositional evolution from the Andes to the lowland Amazon mainstem, Organ. Geochem., 38, 337-364, 2007.

Baker, A.: Fluorescence excitation-emission matrix characterization of river waters impacted by a tissue mill effluent, Envir. Sci. Tech., 36, 1377-1382, 2002.

Benner, R. and Hedges, J.: A test of the accuracy of freshwater DOC measurements by high-temperature catalytic oxidation and UVpromoted persulfate oxidation, Mar. Chem., 41, 161-165, 1993.

Bouillon, S., Abril, G., Borges, A. V., Dehairs, F., Govers, G., Hughes, H. J., Merckx, R., Meysman, F. J. R., Nyunja, J., Osburn, C., and Middelburg, J. J.: Distribution, origin and cycling of carbon in the Tana River (Kenya): a dry season basin-scale survey from headwaters to the delta, Biogeosciences, 6, 2475-2493, doi:10.5194/bg-6-2475-2009, 2009.

Coble, P., Del Castillo, C., and Avril, B.: Distribution and optical properties of CDOM in the Arabian Sea during the 1995 Southwest Monsoon, Deep-Sea Res., Part 2, 45, 2195-2223, 1998.

Conmy, R., Coble, P., Cannizzaro, J., and Heil, C.: Influence of extreme storm events on West Florida Shelf CDOM distributions, J. Geophys. Res., 114, G00F04, doi:10.1029/2009JG000981, 2009. 
Cory, R. M. and McKnight, D. M.: Fluorescence Spectroscopy Reveals Ubiquitous Presence of Oxidized and Reduced Quinones in Dissolved Organic Matter, Environ. Sci. Technol., 39, 81428149, doi:10.1021/es0506962, 2005.

Cory, R. M., Miller, M. P., McKnight, D. M., Guerard, J. J., and Miller, P. L.: Effect of instrument-specific response on the analysis of fulvic acid fluorescence spectra, Limnol. Oceanogr. Meth., 8, 67-78, 2010 .

Ćosović, B.: Surface-Active Properties of the Sea Surface Microlayer and Consequences for Pollution in the Mediterranean Sea, in: The Mediterranean Sea, vol. 5 part $\mathrm{K}$ of The Handbook of Environmental Chemistry, pp. 541-553, Springer Berlin/Heidelberg, doi:10.1007/b107150, 2005.

Ćosović, B. and Vojvodić, V.: The application of ac polarography to the determination of surface-active substances in seawater, Limnol. Oceanogr., 27, 361-369, 1982.

Cunliffe, M., Upstill-Goddard, R. C., and Murrell, J. C.: Microbiology of aquatic surface microlayers, FEMS Microbiol. Rev., 35, 233-246, doi:10.1111/j.1574-6976.2010.00246.x, 2011.

Cunliffe, M., Engel, A., Frka, S., Gašparović, B., Guitart, C., Murrell, J. C., Salter, M., Stolle, C., Upstill-Goddard, R., and Wurl, O.: Sea surface microlayers: A unified physicochemical and biological perspective of the air-ocean interface, Prog. Oceanogr., 109, 104-116, doi:10.1016/j.pocean.2012.08.004, 2013.

Fellman, J., Hood, E., Edwards, R., and D'Amore, D.: Changes in the concentration, biodegradability, and fluorescent properties of dissolved organic matter during stormflows in coastal temperate watersheds, J. Geophys. Res.-Biogeo, 114, G01021, doi:10.1029/2008JG000790, 2009.

Fellman, J. B., Hood, E., and Spencer, R. G. M.: Fluorescence spectroscopy opens new windows into dissolved organic matter dynamics in freshwater ecosystems: A review, Limnol. Oceanogr., 55, 2452-2462, doi:10.4319/lo.2010.55.6.2452, 2010.

Ferrari, G., Dowell, M., Grossi, S., and Targa, C.: Relationship between the optical properties of chromophoric dissolved organic matter and total concentration of dissolved organic carbon in the southern Baltic Sea region, Mar. Chem., 55, 299-316, 1996.

Frew, N. M., Nelson, R. K., Bock, E. J., McGillis, W. R., Edson, J. B., and Hara, T.: Spatial variations in surface microlayer surfactants and their role in modulating air-sea exchange, in: Gas Transfer at Water Surfaces, edited by Donelan, M. A., Saltzman, E. S., Wanninkhof, R., and Drennan, W. M., vol. 127 of Geophysical Monograph Series, 153-159, AGU Press, Washington DC, 2002.

Fu, P., Wu, F., Liu, C., Wang, F., Li, W., Yue, L., and Guo, Q.: Fluorescence characterization of dissolved organic matter in an urban river and its complexation with $\mathrm{Hg}(\mathrm{II})$, Appl. Geochem., 22, 1668-1679, 2007.

Gao, L., Fan, D., Li, D., and Cai, J.: Fluorescence characteristics of chromophoric dissolved organic matter in shallow water along the Zhejiang coasts, southeast China, Marine Environmental Research, 69, 187-197, 2010.

Gardner, W. D., Hinga, K. R., and Marra, J.: Observations on the degradation of biogenic material in the deep ocean with implications on accuracy of sediment trap fluxes, J. Mar. Res., 41, 195214, 1983.

Gardolinski, P., Hanrahan, G., Achterberg, E., Gledhill, M., Tappin, A., House, W., and Worsfold, P.: Comparison of sample storage protocols for the determination of nutrients in natural waters, Wa- ter Res., 35, 3670-3678, 2001.

Garrett, W. D.: Collection of slick-forming materials from the sea surface, Limnol. Oceanogr., 10, 602-605, 1965.

Gašparović, B.: Decreased production of surface-active organic substances as a consequence of the oligotrophication in the northern Adriatic Sea, Est. Coast. Shelf Sci., 115, 33-39, doi:10.1016/j.ecss.2012.02.004, 2012.

Harvey, G. W. and Burzell, L. A.: A simple microlayer method for small samples, Limnol. Oceanogr., 17, 156-157, 1972.

Helms, J. R., Stubbins, A., Ritchie, J. D., Minor, E. C., Kieber, D. J., and Mopper, K.: Absorption spectral slopes and slope ratios as indicators of molecular weight, source, and photobleaching of chromophoric dissolved organic matter, Limnol. Oceanogr., 53, 955-969, doi:10.4319/lo.2008.53.3.0955, 2008.

Hood, E., Fellman, J., Spencer, R., Hernes, P., Edwards, R., DiAmore, D., and Scott, D.: Glaciers as a source of ancient and labile organic matter to the marine environment, Nature, 462, 1044-1048, 2009.

Hudson, N., Baker, A., and Reynolds, D.: Fluorescence analysis of dissolved organic matter in natural, waste and polluted waters A review, River. Res. Applic., 23, 631-649, 2007.

Hudson, N., Baker, A., Reynolds, D., Carliell-Marquet, C., and Ward, D.: Changes in freshwater organic matter fluorescence intensity with freezing/thawing and dehydration/ rehydration, J. Geophys. Res.-Biogeo, 114, G00F08, doi:10.1029/2008JG000915, 2009.

Hunter, K. A. and Liss, P. S.: Polarographic measurement of surface-active material in natural waters, Water Res., 15, 203 215, doi:10.1016/0043-1354(81)90113-5, 1981.

Hur, J., Jung, N., and Shin, J.: Spectroscopic distribution of dissolved organic matter in a dam reservoir impacted by turbid storm runoff, Environ. Monitor. Assess., 133, 53-67, 2007.

Kaplan, L.: Comparison of high-temperature and persulfate oxidation methods for determination of dissolved organic carbon in freshwaters, Limnol. Oceanogr., 37, 1119-1125, 1992.

Kattner, G.: Storage of dissolved inorganic nutrients in seawater: poisoning with mercuric chloride, Mar. Chem., 67, 61-66, 1999.

Kim, J. Y., Lee, C., Cho, M., and Yoon, J.: Enhanced inactivation of E. coli and MS-2 phage by silver ions combined with UV-A and visible light irradiation, Water Res., 42, 356-362, 2008.

Kirkwood, D.: Stability of solutions of nutrient salts during storage, Mar. Chem., 38, 151-164, 1992.

Kratzer, S., Bowers, D., and Tett, P.: Seasonal changes in colour ratios and optically active constituents in the optical Case-2 waters of the Menai Strait, North Wales, Int. J. Remote Sens., 21, 2225-2246, 2000.

Kremling, K. and Brugmann, L.: 2. Filtration and storage, in: Methods of seawater analysis, edited by Grashoff, K., Kremling, K., and Ehrhardt, M., Wiley-TCH, Germany, 3rd Edn., 1999.

Kujawinski, E. B., Farrington, J. W., and Moffett, J. W.: Evidence for grazing-mediated production of dissolved surface-active material by marine protists, Mar. Chem., 77, 133-142, 2002.

Lapworth, D., Gooddy, D., Allen, D., and Old, G.: Understanding groundwater, surface water, and hyporheic zone biogeochemical processes in a Chalk catchment using fluorescence properties of dissolved and colloidal organic matter, J. Geophys. Res.-Biogeo, 114, G00F02, doi:10.1029/2009JG000921, 2009.

Lee, B.-G. and Fisher, N. S.: Decomposition and release of elements from zooplankton debris, Mar. Ecol. Prog. Ser., 88, 117-128, 
1992.

Mitchell, B., Bricaud, A., Carder, K., Cleveland, J., Feraari, G., Gould, R., Kahru, M., Kishino, M., Maske, H., Moisan, T., Moore, L., Nelson, N., Phinney, D., Reynolds, R., Sosik, H., Stramski, D., Tassan, S., Trees, C., Weidemann, A., Wieland, J., and Vodacek, A.: Determination of spectral absorption coefficients of particles, dissolved material and phytoplankton for discrete water samples, in: Ocean Optics Protocols for Satellite Ocean Color Sensor Validation, Revision 2, edited by Fargion, G. and Mueller, J. L., chap. 12, 125-153, NASA Goddard Space Flight Center, Greenbelt, 2000.

Mobed, J., Hemmingsen, S., Autry, J., and McGown, L.: Fluorescence characterisation of IHSS humic substances: total luminescence spectra with absorbance correction, Envir. Sci. Tech., 30, 3061-3066, 1996.

Murphy, K., Stedmon, C., Waite, T., and Ruiz, G.: Distinguishing between terrestrial and autochthonous organic matter sources in marine environments using fluorescence spectroscopy, Mar. Chem., 108, 40-58, 2008.

Patel-Sorrentino, N., Mounier, S., and Benaim, J.: Excitationemission fluorescence matrix to study $\mathrm{pH}$ influence on organic matter fluorescence in the Amazon basin rivers, Water Res., 36, 2571-2581, 2002.

Salter, M. E., Upstill-Goddard, R. C., Nightingale, P. D., Archer, S. D., Blomquist, B., Ho, D. T., Huebert, B., Schlosser, P., and Yang, M.: Impact of an artificial surfactant release on air-sea gas fluxes during Deep Ocean Gas Exchange Experiment II, J. Geophys. Res., 116, C11 016, doi:10.1029/2011JC007023, 2011.

Spencer, R. G, Bolton, L., and Baker, A.: Freeze/thaw and pH effects on freshwater dissolved organic matter fluorescence and absorbance properties from a number of UK locations, Water Res., 41, 2941-2950, 2007a.

Spencer, R. G., Baker, A., Ahad, J. M., Cowie, G. L., Ganeshram, R., Upstill-Goddard, R. C., and Uher, G.: Discriminatory classification of natural and anthropogenic waters in two U.K. estuaries, Sci. Total Environ., 373, 305-323, doi:10.1016/j.scitotenv.2006.10.052, 2007b.

Spencer, R. G, Stubbins, A., Hernes, P., Baker, A., Mopper, K., Aufdenkapme, A., Dyda, R., Mwamba, V., Mangangu, A., Wabakanghanzi, J., and Six, J.: Photochemical degradation of dissolved organic matter and dissolved lignin phenols from the Congo River, J. Geophys. Res.-Biogeo, 114, G03010, doi:10.1029/2009JG000968, 2009.

Spencer, R. G, Hernes, P., Ruf, R., Baker, A., Dyda, R., Stubbins, A., and Six, J.: Temporal controls on dissolved organic matter and lignin biogeochemistry in a pristine tropical river, Democratic Republic of Congo, J. Geophys. Res.-Biogeo, doi:10.1029/2009JG001180, 2010.

Stedmon, C. A. and Bro, R.: Characterizing dissolved organic matter fluorescence with parallel factor analysis: a tutorial, Limnol. Oceanogr., 6, 572-579, 2008.

Stedmon, C. A., Markagera, S., and Bro, R.: Tracing dissolved organic matter in aquatic environments using a new approach to fluorescence spectroscopy, Mar. Chem., 82, 239-254, 2003.
Stubbins, A., Spencer, R., Chen, H., Hatcher, P., Mopper, K., Hernes, P., Mwamba, V., Mangangu, A., Wabakanghanzi, J., and Six, J.: Illuminated darkness: Molecular signatures of Congo River dissolved organic matter and its photochemical alteration as revealed by ultrahigh precision mass spectrometry, Limnol. Oceanogr., 55, 1467-1477, 2010.

Tiltstone, G., Moore, G., Sorensen, K., Rottgers, R., Jorgensen, P., Vicente, V., and Ruddick, K.: Regional validation of MERIS chlorophyll products in North Sea coastal waters, REVAMP Inter-calibration report, EVG 2001-00049, https://earth.esa.int/workshops/mavt_2003/ MAVT-2003_802_REVAMPprotocols3.pdf, 2002.

Upstill-Goddard, R. C., Frost, T., Henry, G. R., Franklin, M., Murrell, J. C., and Owens, N. J. P.: Bacterioneuston control of airwater methane exchange determined with a laboratory gas exchange tank, Global Biogeochem. Cy., 17, 19.1-19.15, 2003.

Walker, S., Amon, R., Stedmon, C., Duan, S., and Louchouarn, P.: The use of PARAFAC modeling to trace terrestrial dissolved organic matter and fingerprint water masses in coastal Canadian Arctic surface waters, J. Geophys. Res.-Biogeo, 114, G00F06, doi:10.1029/2009JG000990, 2009.

Wickland, K., Neff, J., and Aiken, G.: DOC in Alaskan boreal forests: sources, chemical characteristics, and biodegradability, Ecosystems, 10, 1323-1340, 2007.

Wiebinga, C. and de Baar, H.: Determination of the distribution of dissolved organic carbon in the Indian sector of the Southern Ocean, Mar. Chem., 61, 185-201, 1998.

Wurl, O., Miller, L., Röttgers, R., and Vagle, S.: The distribution and fate of surface-active substances in the sea-surface microlayer and water column, Mar. Chem., 115, 1-9, 2009.

Wurl, O., Wurl, E., Miller, L., Johnson, K., and Vagle, S.: Formation and global distribution of sea-surface microlayers, Biogeosciences, 8, 121-135, doi:10.5194/bg-8-121-2011, 2011.

Yamashita, Y. and Jaffe, R.: Characterizing the interactions between trace metals and dissolved organic matter using excitationemission matrix and parallel factor analysis, Envir. Sci. Tech., 42, 7374-7379, 2008.

Yamashita, Y., Cory, R., Nishioka, J., Kuma, K., Tanoue, E., and Jaffe, R.: Fluorescence characteristics of dissolved organic matter in the deep waters of the Okhotsk Sea and the northwestern North Pacific Ocea, Deep-Sea Res. II, 57, 1478-1485, 2010a.

Yamashita, Y., Maie, N., Briceno, and Jaffe, R.: Optical characterization of dissolved organic matter in tropical rivers of the Guayana Shield, Venezuela, J. Geophys. Res.-Biogeo, 115, G00F10, doi:10.1029/2009JG000987, 2010b.

Zuev, B. K., Chudinova, V. V., Kovalenko, V. V., and Yagov, V. V.: The Conditions of Formation of the Chemical Composition of the Sea Surface Microlayer and Techniques for Studying Organic Matter in It, Geochem. Int., 39, 702-710, 2001. 